The Half-crown Atlas of Physical Geography. By Keith Johnston, jun. 3I maps, printed in colours. Small 8vo. (Edinburgh, Johnston.)

THIs atlas astonishes and delights us. For two shillings and sixpence we at last get beautifully finished maps, showing the land and water hemispheres, and the lands which are blessed with an antipodes; a perspectic view of the globe; physical maps of the continents, Australasia, British Isles, and the Holy Land, a geological map of the British Isles, maps of ocean and river systems, ocean basins, winds and storms, annual isothermal lines, and range of temperature, distribution of earthquakes and volcanoes; the geographical distribution of useful plants and species, the chief animals, and varieties of man himself. There are, moreover, notes as to the preparation of the atlas, and an analytical index. We warmly congratulate Messrs. Johnstons on their last achievement, and advise everybody to buy the atlas.

Cassell's Technical Manuals.-I. Linear Drawing. 2. Projection. 3. Bullding Construction. By Ellis A. Davidson. Price $2 s$. each. (London : Cassell, Petter, \& Galpin.)

THESE little books are intended to promote the technical education of artisans, and seem to be well-adapted to facilitate the work of teachers and learners. The manual of Linear Drawing shows the application of practical geometry to trade and manufactures, and has been appropriately chosen as the first volume of a technical series for craftsmen. The methods of constructing geometrical figures are given without the mathematical proofs which usually accompany such problems. The application of some of the figures to decorative and mechanical work is illustrated in diagrams of the trefoil, quatrefoil, toothed wheel, ellipse, \&c. Accuracy is persistently inculcated, and ail the figures are admirably executed. The manual of Projection leads the student many steps further, and treats of the drawing of plans, elevations, and sections of solids. The chapter on isometrical projection explains that system of drawing in a clear and concise manner. In some of the more elaborate figures fewer lines of construction might have been used with advantage. The observations on drawing instruments, and their use, are thoroughly practical. The third treatise elucidates the principles of Building Construction, and gives some useful hints on architectural drawing. It is profusely illustrated with diagrams; these are generally good, but the minor details of a few need correction. C. W. W.

Picture Natural History. (London: Cassell, Peıter, and Galpin.)

WE have submitted this volume to an abler critic than ourselves-to a little boy. $\mathrm{He}$ is delighted with the pictures, and interested in the text. We should like to give it to every little boy and girl we know.

Tommy Try, and what he did in Science. By C. O. G. Napier (of Merchiston), F.G.S. Pp. 302, with 46 Illustrations, by J. D. Cooper, and others. (Chapman \& Hall.)

A Book for boys, in which science and anecdote chase each other through a pleasant narrative, until Tommy Try takes to consulting phrenologists, and then, fortunately for his young readers, brings his memoirs to a close.

\section{THE SUEZ CANAL}

$\mathrm{T} F$ all went well, and we hope it did, yesterday witnessed 1 a grand gathering on the sandy shores of a dreary bay in the Midland Sea-that sea around which so much of history has been enacted, and in whose annals the gathering in question will not be the least noteworthy incident. The Suez Canal-that problem of many centuries-is to be opened in presence of emperors, kings, princes, and potentates; of eminent engineers, famous warriors, and distinguished savants invited from the East and from the West; and while the ceremonial lasts the very dreariest of the dreary wastes that here and there border the blue waters of the Mediterranean will be animated by a brilliant throng and the sound of music; and speeches will be made and healths will be drunk, and all present will join in wishing success to the memorable enterprise, which, for a time, is to furnish to Arab storytellers and Frankish newsmongers a topic to talk about.

Dreary as the region is, it has a history. There marched with invading armies the kings whose names are recorded in Scripture; there Artaxerxes was stayed in his victorious advance by the siege of Pelusium; there are yet to be seen relics of cities and towns named in the "Itinerary" of Antoninus; there Titus marched to the siege of Jerusalem; there Baldwin and his Crusaders took the city of Pharamia: the actors in these and other exploits never dreaming that the sands of the desert, drifted by the winds and by the stream of the Nile, would so bury and alter the surface of the land, that after generations should be puzzled to identify its historical localities.

The question of a canal dates from a very early period. In high floods the waters of the Nile spread to within two or three miles of the Red Sea, which would suggest the idea of a permanent communication between the river and the great Arabian Gulf. This communication was actually established, as is said, under Ptolemy Philadelphus; but of course it fell into neglect, and was buried under the drifting sands, until one of the caliphs had it cleared out, after which there was a navigable canal between the Nile and the Red Sea for more than a hundred years. Then it was again lost, and so completely that its ever having existed became matter of doubt and dispute.

But the main project was a ship canal across the isthmus. There is some tradition that Alexander consulted with his engineer officers as to its feasibility, and that they reported against it on account of the difficulty in preventing the mouth of the canal from silting up. In a later age Sultan Selim, who had been baffled in his scheme for a canal to connect the Don and Volga, resolved on cutting one from Pelusium to Suez; and he took an important step towards accomplishing his purpose, for he conquered the country all across, and made his name a terror to the Arabs. But he did not live to cut the canal. The first Napoleon revived the project, and ordered a survey, during which the long-buried remains of the canal above-mentioned were discovered, and the question as to its having existed was settled. From that time the question of a ship-canal became a standing topic, enlisting divers opinions, among which were some to the effect that the project was simply impossible, because, as the level of the Red Sea was so much higher than that of the Mediterranean, the swift current in one direction would prevent navigation.

During this time of debate, Captain Spratt of the Royal Navy was sent, with the ship Medina, to make a survey along the shores of Egypt and of the Isthmus, of which an account was published by the Admiralty in 1859 , entitled, "An Investigation of the Effect of the prevailing Wave Influence on the Nile's Deposits ;" and this was followed by "A Dissertation on the True Position of Pelusium and Farama." Beginning at the western extremity of the Egyptian coast, Captain Spratt found that the Nile there exerted no influence, but that, owing to the prevalent north-westerly and westerly winds, the deposits brought down by the Nile were drifted to the eastward in prodigious quantity, even to the shores of Syria. This was no hasty conclusion : by a careful series of soundings and dredgings, Captain Spratt determined the identity of the sand along the sea bottom, within a given distance of the shore, with that of the deserts through which the Nile flows, Farther out to sea the sand was coralline, and of an entirely different character, while the Nile drift is made up of quartzose sand, with fine mud and particles of mica. The verifications in this particular were too 


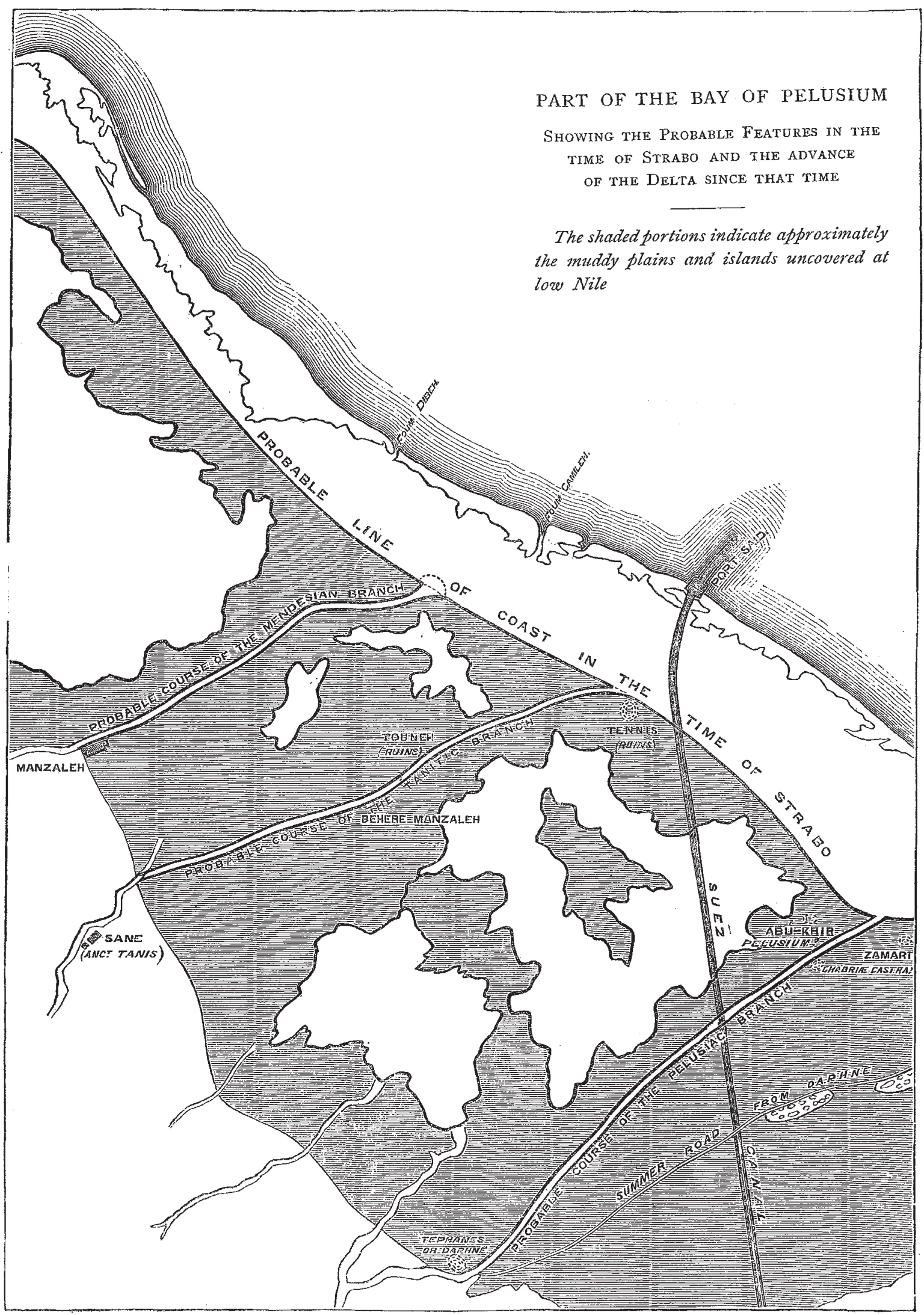


numerous and too exact to leave room for doubt. "By this means," writes Captain Spratt, "I was enabled to trace the extent of the Nile's influence both directly off the coast and along it, as well as to ascertain the large quantity of sand-pure silicious sand-it must annually bring to the sea; and to an amount which far exceeded my expectations and experience in respect to other rivers, particularly that of the Danube, which, in comparison, brings a very much less proportion of sand to mud. The Danube sand, also, is of the finest quality. The Nile sand, on the contrary, is much coarser generally, and forms sandbanks off the coast that are composed of quartzose sand nearly as large as mustard seed."

The quantity of solid matter brought down by the Nile when in flood is prodigious, and precisely at this season - that is, for three or four months - the north-west winds blow strongest. Indeed, if the wind did not blow with the violence of a monsoon it would be impossible for sailing-vessels to navigate the river during the time of its rise. The suspended matter is consequently driven to the eastward along the coast, and there accumulating forms dunes or sandhills, which shift their position with every gale, "burying at times the huts of the coastguard men." The hollows between the dunes are cultivated by the Arabs, but the plots must be protected by screens of reeds, against which the sand accumulates by repetition, until in some instances the hill is a hundred feet in height. Captain Spratt here remarks: "The best efforts of a population of several thousand Arabs, who inhabit the villages along this strip of land, fail in permanently fixing these dunes. For as the sea continually reaccumulates the sand upon the beach; onward it moves, in spite of those efforts, and the rate of progress may be imagined when I state that a mosque near Brulos has in about twelve months been nearly buried in one of the dunes" advancing from the westward. "And as the coarse sand of which these hills are composed is not distinguishable in differing from the sands of the desert near the Pyramids, or that on the route to Suez, they must undoubtedly be all the gifts of the Nile."

Besides coarse sand the Nile carries down fragments of brick, pottery, and other heavy substances, which are also drifted along the coast by the combined action of wind and current. When the wind blows its strongest the coastguard men say they cannot walk against it. To test these facts, Captain Spratt one day landed eleven bags of ashes and clinkers, five of the bags containing pure clinkers, the largest of which weighed from four to five pounds. The whole were laid in a heap just above the water's edge, and left to the care of wind and sea. 'Twelve days later, when the party returned, not a vestige of the heap, which had weighed nearly two tons, was to be seen. The shore was examined towards the quarter from which the wind blew, but without result; while in the other direction, that of the prevailing wave movement, clinkers weighing about two ounces were found dispersed to a distance of fully $\mathbf{1}, 500$ yards, one of $3 \frac{1}{2}$ pounds was picked up at 240 yards, and others from 4 to 8 ounces at from 600 to 700 yards. The greater portion had, however, been buried by the movement of the sand. "Thus this evidence," writes Captain Spratt, " of the movement of the beach in only twelve days, in the month of May, during which there was but one strong westerly breeze and several fresh easterly breezes, is a positive evidence of the great easterly movement of the shore and littoral shallows along this coast, but which, during a succession of winter gales, and during the prevailing north-west breezes at the period of high Nile, must cause a continuous progression of an immense quantity of the sands and matter carried out by the turbid river."

We quote another passage bearing on this point. The captain was walking along the coast for the purpose of observation, from the beacon marking the site of Port Sald, to the head of the bay of Tineh, when he found a great quantity of broken pottery, broken jars, ancient and modern, and broken bricks scattered on the shore, at the highest and lowest surf margin. "On discovering them in such quantity," he continues, "I was naturally anxious to trace out their origin, thinking they must have come from some adjacent ruin. But I found eventually that they had come wholly from the mouths of the Nile, and that they were the positive débris from the towns situated on the banks of the river, and brought out by the strength of the current at high Nile, but then dispersed along the coast to the eastward by its littoral currents and prevailing ground swell."

It would be easy to multiply facts, if further evidence were wanted, that the Nile is no exception in the great transforming powers of Nature, washing down the dry land into the sea, and forming there beneath and on the margin of the waves new continents and islands. The Mississippi, the Ganges, the Yang-tse-Kiang, and other rivers of the great continents, carry down millions of tons of solid matter every year. The North Sea is gradually being silted up by the rivers of Belgium, Holland, and the British islands. At the mouth of the Ebro, on the northern side of the Mediterranean, the deposits brought down by the river are in course of reclamation by an eminent English engineer. Hence we need not feel surprise that the Nile-one of the greatest of rivers-has during long ages wrought great changes on the southern shores of the same sea. In the face of facts such as are above adduced, a government or a nation might well be justified in believing the project of a harbour and canal on. the Bay of Pelusium to be, if not impossible of execution, at least unprofitable. Places which were on the shore when Strabo wrote are now from four to six miles inland, as is shown on the accompanying map, reduced from that published with Captain Spratt's report; and this modifying action is still going on.

Since the Suez canal was first projected engineering science has advanced; and though the sands will accumulate at Port Saïd as from of old, the piers and breakwaters will be periodically lengthened, made to stretch further and further into the sea, while powerful steamdredges will scrape away the sand from the mouth of the harbour. Whether heavy gales will effect any more serious choking of the approaches, or drift tons of blowing sand into the canal itself remains to be seen. But while the world is greeting, and worthily greeting, the great work as a triumph of engineering skill, it may be well, at the same time, to bestow a little thought on the facts and conclusions here brought under notice, which in the pre-scientific age rendered man's contests against the works of the winds and sea perfectly hopeless.

\section{MEETING OF THE AMERICAN ASSOCIATION}

\section{FOR THE ADVANCEMENT OF SCIENCE}

I $N$ the last number of Silliman's fournal is an account of this year's meeting of the American Association, held at Salem, under the presidency of Mr. J. M. Foster, of Chicago, which seems to have passed off as pleasantly and usefully as did our own at Exeter. Over one hundred and fifty new members were elected. The number of communications entered upon the daily programmes of the Standing Committee was about one hundred and fifty. The range of these papers was considerable, and it was found expedient to have sub-sections on Archrology and Microscopy, to facilitate the disposal of papers which could not be reached in the other sections.

The then recent total eclipse of the sun was naturally a prominent subject of interest; the astronomers being present in considerable force.

The dedication of the Peabody Academy of Science was an occasion worthy to occupy the attention of the Association at its opening session. A few notes on this Academy will be welcome to many readers. The Institution 